\title{
The Effects of Teaching Informative Text through Processual Model on Reading Comprehsion Skills ${ }^{*}$
}

\author{
Süleyman Erkam Sulak ${ }^{a,{ }^{* *}}$, Firdevs Güneş ${ }^{b}$
}

\author{
Received: 6 Sept. 2017 \\ Revised: 18 October 2017 \\ Accepted: 25 October 2017 \\ ISSN: 1307-9298 \\ Copyright (c) IEJEE \\ www.iejee.com
}

DOI: 10.26822/iejee.2017236121

\begin{abstract}
This study was carried out in order to search the effects of teaching informative text structures through processual model on the reading comprehension skills of $4^{\text {th }}$ grade students. The research was designed in accordance with experimental model with pre-test-post-test control groups. The study group of the study consisted of 62 fourth grade students who receive their education in 2012-2013 school year in a state school located in the province of Konya, Turkey. Teaching of the informative texts was carried out for 10 weeks based on the processual model in the experimental group, and based on the curriculum of Turkish course in the control group. As data collection tools, Reading Comprehension Test and Awareness Test of Informative Text Structures were used in the research. Mean, standard deviation, unpaired t-test, and one-way analysis of variance were used in the analyses of the study data. Results of the study have revealed that there are significant differences between the reading comprehension levels and awareness of informative text structures on behalf of the experimental group that learned informative texts through processual model.
\end{abstract}

Keywords: Reading comprehension, informative text, text structures, processual model

\section{Introduction}

Increasing the effectiveness of the reading comprehension skills is only possible with the use of various strategies. Using different strategies enables students and teachers to teach and learn texts, and to understand the topic (Dönmez \& Yazıcl, 2006). Good readers have advanced strategies that they use to comprehend what they read (Vacca \& Vacca, 2005).

The demonstration of comprehension strategies by teachers and the teaching of these strategies as models or guides will enable students to learn and use them effectively. Students who successfully learn these strategies will be readers who are independent from their teachers (National Reading Panel [NRP], 2000). At the end of the provided reading trainings, it should be aimed to develop independent readers who can actively use comprehension strategies.

Recently, reading researchers have been especially interested in comprehension trainings and developed various comprehension models. Interactive and processual comprehension models, which are two of the comprehension models developed within the frame of constructivist approach, are commonly known and used (Güneş, 2007).

Processual model is a comprehension model that was developed by Kintsch and Van Dijk (1978). In the related literature, the processual model has names such as situation, construction-integration and comprehension model. According to processual model, in order to understand a text, the information given in the text should be reconstructed in a systematic way. It works in accordance with the principle of creating mental representations in the process of understanding texts. In this model, comprehension processes including the process and mental construction of the information given in the text are explained. At the level of micro structures and macro structures, the information given in the text are chosen, ranked, and organized in accordance with the prior knowledge of the reader, structure of the texts, and the rank of importance. At the level of micro structures, construction of the meaning of a word, a clause, or a sentence is conducted. On the other hand, at the level of macro structures, the meaning of the paragraphs, significant parts, or the whole of the text is conducted. At the same time, organizational structure of the text (description, sequence, cause and effects etc.) is also a macro structure that makes the text easy to understand. Comprehension of the text occurs as a result of the association of the micro and macro structures and prior knowledge of the reader. As these processes are repeated, automatic comprehension skills of the students will improve. With its different aspect, this model is not a model in which only meaning units are generated. It is a model that includes components such as visual images and emotions along with personal experiences (Kintsch \& Dijk, 1978; Kintsch, 2002; Kintsch \& Kintsch, 2005).

\footnotetext{
* This study is a part of Süleyman Erkam Sulak's doctoral dissertation: "The Effect of Procedural Model-Based Informative Text Instruction on Reading Comprehension Skills" supervised by Firdevs Gunes.

a,** Corresponding author: Suleyman Erkam Sulak, Ordu University, Faculty of Education, Ordu, Turkey. Phone: +905398779411, E-mail: erkamsulak@gmail.com

${ }^{\mathrm{b}}$ Ankara University, Faculty of Education, Ankara, Turkey. E-mail : firdevs.gunes@gmail.com
} 


\section{Stages of Processual Model}

Processual model assumes that as a mental skill, comprehension occurs as a result of the mutual interaction of various stages. The reader can reach the meaning of a text as a result of some stages. Cha and Swaffar (1998) stated the stages of processual model as follows:

Stage 1: First of all, the reader determines what is told in the text. At this stage, the topic of the text creates the focal point of the reader.

Stage 2: The reader determines how the text is organized based on the structural signs and the logical relations between the given information. In other words, s/he explains in which structure the text was written.

Stage 3: At this stage, the reader analyses the organization of the text. In order to do that, s/he focuses on the words, sentences, details, and supporting ideas in the text. S/he identifies the relations between ideas by being aware of the structure of the text, and s/he creates supporting ideas. S/he presents the created supporting ideas as a list. $\mathrm{S} / \mathrm{h}$ e reaches the main idea by associating the supporting ideas provided as a list with each other. In order to reach the main idea of the text, the reader should create the links between the ideas in the text again.

Stage 4: At this stage, the reader unifies her/his own perspective and the main idea of the text in order to make inferences. By this means, s/he creates her/his own meaning of the text.

Processual model is an effective model that can be used in the teaching of informative texts, and hence in the development of the comprehension skills (Weaver \& Kintsch, 1996). For this reason, in this study, processual model was used in the teaching of informative texts.

\section{Teaching Informative Texts}

With the Turkish course curriculum dated 2005, the texts were begun to be taught with a thematic approach, and students were begun to be presented various text structures in the genres of narrative, informative, and poetry. This situation indicates that teachers should also draw the attention to the structural differences of the texts in the process of teaching (Akyol, 2007).

Teaching of the informative texts is carried out in two stages;

1.Introducing different informative text structures,

2.Using basic comprehension strategies for each structure (Simonsen, 2004).

Structure of a text reflects the organization of ideas in the text and the relations between these ideas (Armbruster, 2004). In order to improve the comprehension skills of the students, students should be clearly taught how to recognize and use text structures (Dreher \& Gray, 2009; Dymock, 2005; Minskoff, 2005).

While narrative texts, which are more widely known and loved by the students, are included in the first years of elementary school, the number of informative texts increases in the following years. In the process of transition from narrative texts to informative texts, students generally have difficulty in reading and comprehending these texts since their understanding of informative text structures is not developed (Vacca \& Vacca, 2005).

While new vocabulary and terms are more highly given in informative texts, direct personal experiences are less mentioned (Hall, Sabey \& Mcclellan, 2005). At the same time, they are harder to understand compared to narrative texts since they have different structures (Williams, 2005).

Although there is not a mutual classification, researchers generally classify informative text structures in five groups:

\section{Description}

2. Sequence

3. Cause and effect

4. Compare and contrast

5. Problem solving (Gunning, 2005; Meyer,1985, as cited in Moss, 2004; Rozmiarek, 2006; Simonsen 2004; Temple et al. 2005; Vacca \& Vacca, 2005; Williams, 2005)

Informative text structures should be taught separately in company with the appropriate strategies (Dymock, 2005; Gunning, 2005) because the quality of a structure cannot be transferred to other structures (Williams, 2005). For example, in order to understand a text written in the type of "sequence" text structure of a text written in the type of "comparison" cannot be used.

In the teaching of informative texts, identifying of the structure of a text is only the first stage; in the following stage, readers should choose important ideas given in the text and associate them with each other (Gunning, 2005).

Informative texts include topic, main idea, and supporting ideas (Akyol, 1999). Ideas in the text are organized in text structures. A reader who uses the organizational structure of the text can more easily determine the main idea and supporting ideas (Gunning, 2005).

In the teaching of informative texts through processual model, the necessary information about how to apply processes of selection, sequence, and organizing to the paragraphs of the text should be given. It should be explained how the meaning of the text can be generated at the level of micro and macro structures (Kintsch \& Van Dijk, 1978). Also, in the teaching of these types of texts, in order to present the information in a systematic way, graphic organizers should be used, and clue words that are frequently used in the structure of each text should be introduced (Gunning, 2005; Vacca \& Vacca, 2005).

In the first years of elementary school, most teachers do not attach much importance to informative texts. One of the reasons of this situation is that teachers assume that students can understand when they read informative texts (Read, Reutzel \& Fawson, 2008). This situation causes a significant decrease in the reading success of the students after the third grade of the elementary school. 
Thus, in the following years, students find it difficult to keep up with their increasing demand to understand. The effective teaching of informative texts especially at the level of $4^{\text {th }}$ grade has a critical importance in students' understanding of informative texts that they will come across in the upcoming periods (Hall, Sabey \& McClellan, 2005). For this reason, informative texts should be taught from the very first years of the educational process with appropriate models, methods, and strategies.

In Turkey, there are a limited number of studies carried out about the teaching of informative texts. Some of the conducted researches focus on the summarizing skills in informative texts (Çakır, 1995; Çıkrıkçı, 2004; Görgen, 1997; Keçik, 1993). And some researches were carried out towards university students. For example, in her study, Kuzu (2003) searched the effects of the reading training based on transactional model on the junior college students' understanding level regarding to informative texts. However, at the level of elementary school, there is not any study in which informative texts are taught through a model and its effects on the students' comprehension levels are tested. For this reason, a study about this subject was needed.

The aim of this study is to identify the effects of teaching informative text structures through processual model on the reading comprehension skills of $4^{\text {th }}$ grade students. In order to reach this aim, answers of the following questions were looked for:

1. Is there a significant difference between "the informative text structure awareness" of the students in the control group and of the students in the experimental group who have learned informative text types (description, sequence, cause and effect, and problem solving) through processual model?

2. Is there a significant difference between "comprehension levels" of the students in the control group and of the students in the experimental group who have learned informative text types (description, sequence, comparison, cause and effect, and problem solving) through processual model?

\section{Methodology}

\section{Research Model}

The research was designed in accordance with quasiexperimental model with pre-test-post-test control groups. In the quasi-experimental research model, participants are not objectively appointed to experimental and control groups. The researcher uses the available groups (Creswell, 2003). For this reason, quasiexperimental model is an efficient model that can be used especially in educational studies.

\section{Participant}

The study group of this research consisted of 62 fourth grade students who receive their education in 2012-2013 school year in a state school, which is considered to be in middle socio-economic class and located in the province of Konya, Turkey.

In order to determine the experimental and control groups, reading comprehension test in the type of description was applied to the $4^{\text {th }}$ graders of the experimental school. It was tested through one-way analysis of variance (ANOVA) whether there was a significant difference between the scores (gotten out of $100)$ of the classes or not; and the results are given in Table 1.

Table 1. ANOVA results of reading comprehension pretest scores of the students in the experimental school

\begin{tabular}{cccccc}
\hline Class & $n$ & $M$ & SD & $f$ & $p$ \\
\hline 4A & 32 & 28.28 & 12.61 & & \\
4B & 30 & 25 & 11.96 & & \\
4C & 30 & 29.17 & 20.26 & 0.967 & $0.427^{*}$ \\
4D & 30 & 28.67 & 10.90 & & \\
4E & 30 & 23.33 & 14.28 & & \\
\hline${ }^{*} p>0.05$ & & & & &
\end{tabular}

When Table 1 is analysed, it is observed that raw scores vary between 23.33 and 29.17. However, there was not a statistically significant difference between the scores gotten from the test by the classes $(p>0.05)$. Therefore, experimental groups and control groups were randomly chosen from the classes of which means were close to each other. Within this context, between the matched classes, 4-D class was chosen as the experimental group and 4-A class was chosen as the control group.

\section{Measures}

Reading Comprehension Test: The test was developed by the researcher through analysing the relevant literature and obtaining expert opinions. In order to prepare the reading comprehension test, first of all, reading comprehension achievements for the $4^{\text {th }}$ graders who were in the 2005 Turkish course curriculum were identified. A 65-question reading comprehension test including open-ended and multiple-choice questions, which were appropriate for the selected achievements, was prepared. The prepared reading comprehension test was applied to 115 students who have received education in the $4^{\text {th }}$ grade of a state school.

In the item analysis carried out at the end of the practice, the items of which discrimination index were under .20 and the items in which there was not any difference between independent samples t-test and $27 \%$ slice of the subgroups and supergroups were not considered as distinctive, and 15 questions were omitted from the test. As a result, a 50-question Reading Comprehension Test was acquired. Reading comprehension test consisted of five parts (description, sequence, comparison, cause and effect, and problem solving). In each comprehension test, there were 10 questions as being 5 multiple-choice questions and 5 open-ended questions.

Cronbach's alpha coefficients of the reading comprehension test were calculated as follows: 0.75 for comprehension test of the description type, 0.75 for comprehension test of the sequence type, 0.72 for comprehension test of the comparison type, 0.76 for comprehension test of the cause and effect type, and 0.81 for comprehension test of the problem solving type. Reliability coefficient of the general reading comprehension test (50-items) was 0.80 . 
During the scoring of test items, for the multiple-choice questions, wrong answers were calculated as 0 point and correct answers were calculated as 1 point; and for the open-ended questions, wrong answers were calculated as 0 point, incomplete answers were calculated as 1 point, and correct answers were calculated as 2 points.

Awareness Test of Informative Text Structures: The test was developed by the researcher through analysing the relevant literature and obtaining expert opinions. In order to assess the students' knowledge about informative texts, short paragraphs from Turkish textbooks, which presented informative text structures, were selected. Questions about the structures of these paragraphs were asked in multiple-question form. Also, clue words that were frequently used in informative text structures and questions about the structural qualities of the texts were used in the test. As a result of the expert opinions, the awareness test of informative text structures consisting of 15 multiple-choice questions was acquired. For item analysis and score reliability, the test was applied to 120 students who have received education in the $4^{\text {th }}$ grade of a state school.

When item discrimination coefficients of the test items were analysed, it was observed to be higher than 0.20. Therefore, no item was omitted from the test. The test's Cronbach's alpha coefficient was calculated as 0.76 .

\section{Process}

The lessons in the experimental group were carried out by the researcher while the lessons in the control group were carried out by the class teacher. Studies were carried out for 10 weeks as being 2 weeks for the awareness program about the conducted method and 8 weeks for the practice process.

In the experimental group, the teaching of the informative texts was carried out in accordance with processual model. Within the scope of the stages stated by Cha and Swaffar (1998), various activities and strategies before, during, and after the reading of informative texts were used. These activities and strategies were prepared through using the studies of several researchers (Duke \& Pearson, 2002; Hall, Sabey \& McClellan, 2005; Hoffman, 2010; Gunning, 2005; Güneş, 2007; Karatay, 2011; NRP, 2000; Schirmer, 2010; Temple et al., 2005; Tompkins, 2006; Vacca \& Vacca, 2005).

Before the reading, activities and strategies of creating the aim of reading, activating the prior knowledge, checking the title and text, estimating, brain storming, studying with the vocabulary, and KWL were used.

During the reading, reading activities, activities of underlining the important words and statements, finding clue words, and questioning and answering were used.

After the reading, activities of retelling, identifying the topic, finding the supporting ideas, finding the main topic, identifying the aim of the writer, graphic organizers, and summarizing were used.

Each text structure was separately taught in the experimental group. First of all, the training was started with the text structure of the description type. And then, the text structures of the types of $r$ sequence, comparison, cause and effect, and problem solving were taught.

The teaching of the informative texts in the control group was carried out in accordance with the stages given in the teacher's guidebook of the Turkish lesson.

\section{Data Analysis}

Arithmetic mean, standard deviation, unpaired test, and one-way analysis of variance were used in the analyses of the study data. The data obtained from the research was analysed through the use of SPSS 16.0 statistical package program. Raw scores acquired from the pre-tests and post-tests of the research were re-calculated over 100 points.

It was analysed with Kolmogorov-Smirnov test whether the scores acquired from the pre-tests and post-tests of the research indicated normal distribution or not. Since the data ranged between normal values, parametric tests were used.

At the stage of identifying the equivalences of the classes, one-way analysis of variance (ANOVA) was used to determine whether there was a significant difference between the scores gotten by different classes or not.

Unpaired t test was used to determine whether there was a significant difference between the pre-test and post-test scores of the students from the experimental group and the control group.

\section{Results}

\section{Awareness of Informative Text Structures}

It was tested through the unpaired $t$-test whether there was a significant difference between "the informative text structure awareness" of the students in the control group and of the students in the experimental group and the results are given in Table 2 .

Table 2. T-test Results of The Experimental Group and Control Group Students' Pre/Post Test Scores with Regard to The Informative Text Structure Awareness

\begin{tabular}{lcccccc}
\hline & & $n$ & $M$ & $\mathrm{SD}$ & $t$ & $p$ \\
\hline $\begin{array}{l}\text { pre- } \\
\text { test }\end{array}$ & $\mathrm{EG}$ & 30 & 45.78 & 21.71 & -1.126 & $0.265^{*}$ \\
\hline $\begin{array}{l}\text { post- } \\
\text { test }\end{array}$ & $\mathrm{EG}$ & 32 & 51.46 & 17.94 & & \\
\hline \multirow{2}{*}{$p>0.05 ;$} & CG & 32 & 52.67 & 11.69 & 6.342 & $0.000^{* *}$ \\
\end{tabular}

As seen in Table 2, it is observed that the control group students' level of knowledge with regard to the text structures measured before the practice $(M=51.46)$ was higher compared to the experimental group students' levels $(M=45.78)$. However, there is not a significant difference between the experimental group and control group students' levels of text structure knowledge, which were measured before the practice $(p>0.05)$.

It is observed that the experimental group students' leve/ of knowledge with regard to the text structures measured after the practice ( $M=82.67$ ) was higher compared to the 
control group students' level ( $M=53.33$ ). A significant difference on the behalf of the experimental group was found between the experimental group and control group students' levels of text structure knowledge, which were measured after the practice $(p<0.05)$.
It was tested through the unpaired $t$-test whether there was a significant difference between the experimental group and control group students' reading comprehension levels, which were measured before the practice, and the results are given in Table 3.

\section{Reading Comprehension Levels}

Table 3. T-test Results of The Experimental Group and Control Group Students' Pre-Test Scores with Regard to Their Levels of Reading Comprehension

\begin{tabular}{|c|c|c|c|c|c|c|}
\hline pre-test & & $n$ & $M$ & SD & $t$ & $p$ \\
\hline \multirow{2}{*}{ Description } & EG & 30 & 38.22 & 14.54 & 0.128 & $0.898^{*}$ \\
\hline & CG & 32 & 37.71 & 16.82 & & \\
\hline \multirow{2}{*}{ Sequence } & EG & 30 & 44.44 & 12.67 & 0.932 & 0.355 \\
\hline & CG & 32 & 40.63 & 18.81 & & \\
\hline \multirow{2}{*}{ Cause-effect } & EG & 30 & 49.11 & 18.98 & 0.252 & $0.802^{*}$ \\
\hline & CG & 32 & 47.92 & 18.27 & & \\
\hline \multirow{2}{*}{ Compare-contrast } & EG & 30 & 38.22 & 13.44 & 1.845 & $0.070 *$ \\
\hline & CG & 32 & 31.88 & 13.62 & & \\
\hline \multirow{2}{*}{ Problem solving } & EG & 30 & 33.78 & 15.46 & -1.242 & $0.219 *$ \\
\hline & CG & 32 & 38.54 & 14.74 & & \\
\hline \multirow{2}{*}{ Reading Comprehension } & EG & 30 & 40.76 & 11.44 & 0.460 & $0.647 *$ \\
\hline & CG & 32 & 39.33 & 12.81 & & \\
\hline
\end{tabular}

When Table 3 is analysed, it is observed that the experimental group students' reading comprehension levels with regard to description $(M=38.22)$, sequence $(M=$ 44.44), cause and effect ( $M=49.11)$, and comparison ( $M=$ 38.22), which were measured before the practice, were higher compared to the levels of control group students. On the other hand, reading comprehension level of the control group students with regard to the problem solving ( $M=38.54$ ) was found higher compared to the level of experimental group students. However, there is not a statistically significant difference between the experimental group and control group students' levels of reading comprehension with regard to description, sequence, comparison, cause and effect, and problem solving skills, which were measured before the practice $(p>0.05)$.

It was tested through the unpaired $t$-test whether there was a significant difference between the experimental group and control group students' reading comprehension levels which were measured after the practice and the results are given in Table 4.

Table 4. T-test Results of The Experimental Group and Control Group Students' Post-Test Scores with Regard to Their Levels of Reading Comprehension

\begin{tabular}{|c|c|c|c|c|c|c|}
\hline post-test & & $n$ & $M$ & SD & $t$ & $p$ \\
\hline \multirow{2}{*}{ Description } & EG & 30 & 70.00 & 14.73 & 5.531 & $0.000 *$ \\
\hline & CG & 32 & 46.25 & 18.70 & & \\
\hline \multirow{2}{*}{ Sequence } & EG & 30 & 72.89 & 13.33 & 7.213 & $0.000 *$ \\
\hline & CG & 32 & 43.13 & 18.55 & & \\
\hline \multirow{2}{*}{ Cause-effect } & EG & 30 & 66.89 & 18.24 & 2.912 & $0.005^{*}$ \\
\hline & CG & 32 & 53.33 & 18.39 & & \\
\hline \multirow{2}{*}{ Compare-contrast } & EG & 30 & 63.55 & 16.40 & 4.244 & $0.000 *$ \\
\hline & CG & 32 & 45.00 & 17.92 & & \\
\hline \multirow{2}{*}{ Problem solving } & EG & 30 & 63.33 & 18.34 & 3.090 & $0.003^{*}$ \\
\hline & CG & 32 & 47.50 & 21.73 & & \\
\hline \multirow{2}{*}{ Reading Comprehension } & EG & 30 & 67.33 & 14.26 & 5.193 & $0.000 *$ \\
\hline & CG & 32 & 47.04 & 16.36 & & \\
\hline
\end{tabular}

$*_{p}<0.05$

When Table 4 is analysed, it is observed that the experimental group students' reading comprehension levels with regard to description ( $M=70.00)$, sequence ( $M=$ 72.89), cause and effect ( $M=66.89)$, comparison $(M=$ 63.55), and problem solving $(M=63.33)$ which were measured after the practice, were higher compared to the levels of control group students. And statistically, a significant difference was found between the experimental group and control group students' levels of reading comprehension with regard to description, 
sequence, comparison, cause and effect, and problem solving skills, which were measured after the practice $(p<0.05)$.

General reading comprehension level of the experimental group students, measured after the practice, was found higher ( $M=67.33$ ) compared to the level of control group students $(M=47.04)$. And statistically, a significant difference was found between the experimental group and control group students' levels of general reading comprehension measured after the practice $(p<0.05)$. The acquired difference is on the behalf of the experimental group.

When the post-test scores obtained by the experimental group students after the practice are analysed, it is observed that they succeeded most in the sequence type comprehension test $(M=72.89)$, and then in description $(M=70.00)$, cause and effect $(M=66.89)$, comparison $(M=$ 63.55), and problem solving ( $M=63.33$ ) comprehension tests.

\section{Discussion}

According to the results of the research, reading comprehension skills of the students who learned the informative texts through the effective strategies developed in a positive way. These findings show similarity with the findings of the researchers who have taught informative text structures through various strategies (Baştuğ \& Keskin, 2011; Dreher \& Gray, 2009; Hall et al., 2005; Hoffman, 2010; Mcginley, 2008; Newman, 2007; Nubla-Kung, 2008; Özmen, 2011; Reutzel, Read \& Fawson, 2009; Stagliano \& Boon, 2009; Williams, 2005; Williams, 2008).

In the conclusions of the studies mentioned above, it is stated that the teaching of text structures has positive effects on reading comprehension. These findings have the quality to support the results of the research.

In the teaching of informative text through processual model, learning the structure of a text is the first stage. In the following stage, readers should choose important ideas given in the text and associate them with each other (Gunning, 2005). At this stage of the research, activities that would help students to make arrangements between the important ideas given in the text were used. With the help of these activities, students could organize supporting ideas and could more easily and systematically identify the main idea of the text, topic, and the aim of the writer.

According to the results of the research, the average value of the scores that students from the experimental group got from the "sequence" type, one of the reading comprehension tests applied after the practice, was higher compared to other tests. And, the types of "description", "cause and effect", and "comparison" followed it. The minimum point average was observed in reading comprehension test of the "problem solving" type. These results showed similarities with the findings that Sharp (2004) acquired from his study. In his study, Sharp (2004) assessed the informative text (description, sequence, cause and effect, and problem solving) comprehension skills of the students in the study group through gap-filling and recall tests. According to the results of the study, the students succeeded most in understanding the texts written in "sequence" type. And, texts written in "description" and "cause and effect" types followed it. The text type in which the reading comprehension level was the lowest was "problem solving"type.

In conclusion, the findings of this research show similarities with the findings of other researches in the literature. According to the results of the research, the teaching of informative texts through processual model develops the reading comprehension skills of students.

\section{References}

Akyol, H. (2007). Türkçe öğretim programı: Yenilikler ve sorunlar. Ilköğretmen Dergisi, 61.

Akyol, H. (1999). Bilgi vermeye dayalı metinler ve öğretimi. Çă̆daş Ĕgitim Dergisi, 253, 7-13.

Armbruster, B.B. (2004). Considerate texts. In D. Lapp, J. Flood and N. Farnan (Eds.), Content area reading and learning: Instructional strategies (pp. 47-58). Mahwah, NJ: Erlbaum.

Baştuğ, M. \& Keskin, K. (2011). Bilgilendirici metin yapılarının öğretiminin okuduğunu anlamaya etkisi. eJournal of New World Sciences Academy, 6(4), 25982610.

Cha, K. A. \& Swaffar, J. (1998). The case for a procedural model as a multiple measure of reading comprehension. System, 26, 205-222.

Creswell, J. W. (2003). Research design: Qualitative, quantitative, and mixed methods approaches. London: Sage Publications.

Çakır, Ö. (1995). Büyük ö/çekli kuralların öğretiminin okuduğunu anlamaya etkisi, (Unpublished doctoral dissertation). Hacettepe Üniversitesi Sosyal Bilimler Enstitüsü, Ankara.

Çıkrıkçı, S. (2004). ilköğretim öğrencilerinde özetleme becerisinin gelişimi, (Unpublished doctoral dissertation). Ankara Üniversitesi Sosyal Bilimler Enstitüsü, Ankara.

Dönmez, C. \& Yazıcı, K. (2006). Sosyal bilgilerde öğrencilerin okuduğunu anlama becerilerinin geliştirilmesinde metin yapısına bağı olarak kullanılabilecek strateji ve teknikler. Manas Üniversitesi Sosyal Bilimler Dergisi, 16,138-154.

Dreher, M.J. \& Gray, J.L. (2009). Compare, contrast, comprehend: using compare-contrast text structures with ells in K-3 classrooms. Reading Teacher, 63(2), 132-141.

Duke, N. K. \& Pearson, P. (2002). Effective practices for developing reading comprehension. In A.E. Farstrup, \& S. Samuels (Eds.), What Research Has to Say About Reading Instruction(pp. 205-242). Newark, DE: International Reading Association.

Dymock, S. (2005). Teaching expository text structure awareness. The Reading Teacher, 59(2), 177-181. 
Görgen, i. (1997). Özetleme ve bilgi haritası oluşturma ögretiminin bilgilendirici bir metni öğrenme ve hatırlama düzeyine etkisi, (Unpublished doctoral dissertation). Hacettepe Üniversitesi Sosyal Bilimler Enstitüsü, Ankara.

Gunning, T. G. (2005). Creating literacy instruction for all students (5th ed.). Boston: Allyn and Bacon.

Güneş, F. (2007). Türkçe öğretimi ve zihinsel yapılandırma. Ankara: Nobel Yayıncilık.

Hall, K.M., Sabey, B.L. \& Mcclellan, M. (2005). Expository text comprehension: helping primary-grade teachers use expository texts to full advantage. Reading Psychology, 26, 211-234.

Hoffman, K. F. (2010). The impact of graphic organizer and metacognitive monitoring instruction on expository science text comprehension in fifth grade students, (Unpublished doctoral dissertation). University of North Carolina State, North Carolina.

Karatay, H. (2011). Okuma eğitimi kuram ve uygulama. Ankara: Berikan yayınevi.

Keçik, i. (1993). ilkokul 2. ve 5. sınıf öğrencilerinin hatırlama ve özet metinlerinde uygulanan büyük ölçekli yapı kuralları, Dilbilim Araştırmaları, (p. 89-97), Ankara: Hitit Yayınevi.

Kintsch, W. \& VanDijk, T. A. (1978). Toward a model of text comprehension and production. Psychological Review, 85, 363-394.

Kintsch, W. (2002). On the notions of theme and topic in psychological process models of text comprehension. in M. Louwerse and W. van Peer (Eds.), Thematics: Interdisciplinary Studies (pp. 157-170). Amsterdam: Benjamins.

Kintsch W. \& Kintsch, E. (2005). Comprehension. In S. G. Paris and S. A. Stahl (Eds.), Current issues in reading comprehension and assessment (pp. 71-92). Mahwah, NJ: Lawrence Erlbaum Associates.

Kuzu, T.S. (2003). Etkileşimsel model'e uygun okuma öğretiminin Türkçe bilgilendirici metinleri anlama düzeyine etkisi, (Unpublished doctoral dissertation). Ankara Üniversitesi Eğitim Bilimleri Enstitüsü, Ankara.

McGinley, D. L. (2008). Effects of guided reading on motivation and comprehension in reading expository texts (Unpublished graduate dissertation). Caldwell College, Program of Curriculum and Instruction.

Minskoff, (2005). Teaching reading to struggling lerarners. Maryland: Paul H. Brookes Publishing.

Moss, B. (2004). Teaching expository text structures through information trade book retellings. The Reading Teacher, 578), 710-718.

National Reading Panel. (2000). Report of the National Reading Panel. Teaching children to read: An evidence-based assessment of the scientific research literature on reading and its implications for reading instruction. Web: https://www.nichd.nih.gov/publicati ons/pubs/nrp/Documents/report.pdf
Newman, L. M. (2007). The effects of explicit instruction of expository text structure incorporating graphic organizers on the comprehension of third-grade students, Nnpublished doctoral dissertation). University of Maryland.

Nubla-Kung, A. M. (2008). The effects of text structure and signals on second graders' recall and comprehension of expository text, Unpublished doctoral dissertation). University of Columbia.

Özmen, R.G. (2011). Zihinsel yetersizliği olan öğrencilerin bilgi veren metinlerdeki bilgiler hatırlamalarında şematik düzenleyicilerin iki farklı sunum şeklinin karşılaştırılması. Kuram ve uygulamada eğitim bilimleri, 11(2), 785-793.

Read, S., Reutzel, D., \& Fawson, P., (2008). Do you want to know what I learned? using informational trade books as models to teach text structure. Early Childhood Education Journal, 36(3), 213-219.

Rozmiarek, R. (2006). Improving reading skills across the content areas. California: Corwin Press.

Schirmer, B. R. (2010). Teaching the struggling reader. Boston: Pearson-Allyn and Bacon.

Sharp, A. (2004). Strategies and predilections in reading expository text: The importance of text patterns. RELC, 35(3), 329-349.

Simonsen, S. (2004). Identifying and teaching text structures in content area classrooms. In D. Lapp, J. Flood, \& N. Farnan (Eds.), Content area reading and learning: Instructional strategies. Mahwah, NJ: Erlbaum.

Stagliano, C. \& Boon, R. T. (2009). The effects of a storymapping procedure to improve the comprehension skills of expository text passages for elementary students with learning disabilities. Learning Disabilities: A Contemporary Journal, 72), 35-58.

Temple, C., Ogle, D., Crawford, A. \& Freppon, P. (2005). Al/ children read: teaching for literacy in diverse classrooms. New York: Addison Wesley Longman.

Tompkins, G.E. (2006). Literacy for the 21st century: a balanced approach. Upper Saddle River, NJ: Prentice Hall.

Weaver, C. A. and Kintsch, W. (1996). Expository Text. In R. Barr et al. (eds.), Handbook of Reading Research (Volume II, pp.230-245). Mahwah, New Jersey: Lawrence Erlbaum Associates.

Williams, J.P. (2005). Instruction in reading comprehension for primary-grade students: a focus on text structure. The Journal Of Special Education, 39(1), 6-18.

Williams, J. P. (2008). Explicit instruction can help primary students learn to comprehend expository text. In C. C. Block and S. R. Parris (Eds.), Comprehension processes: Research-based best practices, (2nd edition). New York: Guilford Press.

Vacca, R. T. \& Vacca, J. L. (2005). Content area reading. (Eighth Edition). Boston: Pearson Education. 
This page is intentionally left blank

www.iejee.com 